\title{
The Position of Honorary Council of Notary in Coaching Indonesian Notaries
}

\author{
Hatta Isnaini Wahyu Utomo ${ }^{1} \quad$ Slamet Suhartono $^{2} \quad$ Moch. Isnaeni $^{3}$ \\ 1.Doctoral Degree Student of Law of 17 Agustus 1945 University Surabaya and Lecturer of Law Faculty of Yos \\ Sudarso University, Surabaya \\ 2.Lecturer of Law Faculty of 17 Agustus 1945 University Surabaya \\ 3.Lecturer of Law Faculty of Airlangga University and 17 Agustus 1945 University Surabaya
}

\begin{abstract}
The Honorary Council of Notary is formed by the Ministry in which its function is to develop notarial skills in performing their duty. As the part of state administration department, all acts are representing the state.. All government actions (bestuurshandelingen) must be based on a clear legal basis (legality). Procedure errors carried out by the Honorary Council of Notary in granting permission to take Minuta deed and to call a Notary still occur due to a lack of understanding in regard to the nature tasks of the Notary Honorary Council. The present study examines about the philosophical foundation of the Honorary Council of Notary. The research method used is normative legal research by examining literary sources or secondary legal materials while the problem approach is carried out by using a legal and conceptual approaches. The present study indicates that position of Notary is a trusting position where the community entrust their will therefore it must be maintained and kept by the Notary. The existence of the Honorary Council of Notary is intended to provide legal protection for Notary in maintaining confidentiality of the deed in order to avoid arbitrary acts of law enforcement in the process of criminal case examinations relating to the making of authentic deeds by the notary.
\end{abstract}

Keywords : Notary, The Honorary Council of Notary, Notarial Management

DOI: $10.7176 / J L P G / 92-12$

Publication date: December $31^{\text {st }} 2019$

\section{INTRODUCTION}

The enactment of Law No 2, 2014 concerning Amendment to Law No 30, 2004 concerning Notary Position (UUJN Amendment) stimulate establishment of new institution in terms of guidance to Notary, namely The Honorary Council of Notary. The Honorary Council of Notary is a body that holds authority to provide guidance for the notary and give approval or rejection concerning submission of deed copies coupled with calling the notary to attend examination regarding the deed for the purposes of investigation and judicial process.

The establishment of Honorary Council of Notary is based on the position of notary as public official who runs a profession in providing legal services to the public in which the notary also need protection and guarantee to achieve legal certainty. The legal protection provided for the notary is not solely aimed for them, but rather to grant legal protection for the parties concerning confidentiality of the deed. The presence of the Notary Honorary Council is expected to maintain the confidentiality of the deeds, especially in the event of dispute therefore no party is harmed due to confidentiality disclosure of the deeds. Article 66 paragraph (1) UUJN Amendment is stated: In accordance with the judicial process, investigators, public prosecutors, or judges with the approval of the Honorary Council of Notary, they are authorised: a) take copies Deed and / or letters attached to the Deed or Protocol in the storage of a Notary; and b) summon the notary to attend the inspection about Deed or Protocol that is kept in the storage of the notary.

The Honorary Council of Notary is formed by the Minister in the framework of managing the position of Notary. As a State Administration Agency, all actions taken by the Honorary Council of Notary in carrying out their duties and authorities are on behalf of the government. All government actions (bestuurshandelingen) must be based on a clear legal basis (legality) (Utomo, 2017). Absence of legal proceedings for the Honorary Council of Notary stimulates various procedural errors committed by this council in granting permits for taking deeds and calling notary to be inspected in which it will be harmed the Notary both materially and immaterial. Material losses can be seen from the amount of time wasted and costs incurred by a Notary to fulfil calls from investigators. Meanwhile, the immaterial loss is related to the Notary's good name due to summon by the investigator. This condition led to a conflict between the Honorary Council of Notary as representative of the government and Notary. Therefore, it required further study about philosophical basis related to establishment of the Honorary Council of Notary.

\section{METHOD}

The present study uses a normative legal research method that is conducted in finding solutions for legal matters. The research approach used is the statute and conceptual approaches. 


\section{DISUCSSION}

Notary is a State official or public official who can be appointed by the State to carry out duties in legal services for the community in order to achieve legal certainty as an official maker of authentic deeds in terms of civil. Public officials mean people who are appointed to occupy public positions by the state to carry out duties or responsibilities.

Public service is main task of the government based on the principle of providing and guaranteeing existence of legal certainty for citizens of the community member. In certain sectors, duties mentioned above are given and entrusted to notary, therefore the community member must believe that notarial deed provides legal certainty for them. The existence of authority granted by law coupled with trust from the community is the basis of duties and functions of notary in legal traffic.

The notary in carrying out their duties is obliged to keep deed and all information obtained in process of making the deed, unless they are instructed by the law not to keep confidentiality and provide necessary information relating to the deed. Therefore, the main obligation for the notary is clear to maintain confidentiality of the deed based on law or regulation. Obligation in maintaining the confidentiality of deed is stated clearly based on official oath of notary which is known as professional privilege (Verschoningsplicht). The existence of mentioned above privilege is not only for the benefit of the notary but also to protect interests of the parties that are entrusted to the notary.

Obligation in maintaining the confidentiality is part of profession promise which must be maintained by notary based on their oath before they perform their duty as the notary public (Utomo, Memahami Pelaksanaan Tugas Jabatan Pejabat Pembuat Akta Tanah, 2019) (Utomo, 2019). The word "rahasia" (secret) comes from Sanskrit language rahas-ja which means it cannot be told to the others (Kohar, 1984). Meanwhile in English "rahasia" is known as secret. According to Thordike English Dictionary, secret means : 1) Keep from knowledge of others; 2)Keeping to one self what one knows; 3)Known only a few; 4)Keep from sight; hidden. Based on descriptions mentioned above, A. Kohar summarised that secret is something that cannot be seen, read, felt and heard by others, in other words it can be said that secret is something that no one else should know (Kohar, 1984). Confidential things are commonly related to profession. Therefore, some professions are commonly preceded by an oath before appointed to his/her position.

Ko Tjay Sing stated that there are 3 (three) theories related to confidentiality of profession which are: 1) Absolute Secret Theory, namely the obligation to keep the secret under any circumstances. It must be maintained, likewise, if by not disclosing the secret, the interests must be greater than the secret that are protected; 2) Relative Secret Theory, namely obligation to maintain secret that can be abandoned if by storing their secrets must be sacrificed interests that are considered greater. Therefore conflicting interests must be compared with one another. Those who are considered bigger must be protected, others must be sacrificed; 3) A theory that wants to eliminate the secret of work, it is the contrary of absolute secret theory in which this theory encourages to reject one hundred percent of the confidential recognition of work. According to this theory the right to resign for people with work of trust must be revoked (Sing, 1978). Obligation to keep the secret of work or confidential position, must meet the requirements: 1) There must be an obligation to keep secrets because of work or position and dignity; 2) It also related to confession entrusted to depositor; 3) What is delivered must have a secret nature.

Related to the confidential position of notary, Tan Thong Kie argues that society in general as well as society in the business world needs someone (figure) that can be rely on, trusted, able to provide guarantee coupled with strong legal evidence, an objective expertise, counsellor that onkreukbaar or unimpeachable, and able to make legal contract which can be used in the future. If an advocate defends someone's rights when a difficulty arises, then a notary must try to prevent the occurrence of these difficulties or matters (Kie, 2000).

Oath that is spoken by notary to maintain confidentiality of the deed is an embodiment of the Principle of Trust which becomes a guideline for the notary in carrying out his position. The oath or promise is something that must be understood, namely that the community believes that the notary is able to store all the statements or sayings given before the notary. On this base, the position as notary is a trusted position. One form that stimulate position of notary as a position of trust is the obligation to keep everything about the deed made and all information obtained to make deeds in accordance with the oath / promise of the profession. Exceptions to these obligations are only limited if the Law determines otherwise (Adjie, 2008).

Notary is appointed and dismissed by the Minister of Law and Human Rights (formerly it is called the Minister of Justice). The appointment of a notary is not for the self-interest of the notary but for interests of people who will be served, therefore, since the presence of notary institutions in Indonesia, supervision is always carried out toward performance of notary. In every organisation mainly government organisation, supervision and guidance have important function since it is able to maintain continuity operation of government in efficient and effective manners.

As a logical consequence along with the notary's responsibility to the public, then continuous supervision and guidance must be taken therefore notary is always in accordance with the legal rules that underlie their authority, avoid abuse of authority and trust that are given. Moreover, in order to maintain ethical and legal 
values according to existing laws, supervision toward notary is urgently needed. The purpose of supervision toward notary is to fulfil the requirements and carry out their duties in accordance with the provisions and secure public interests. Furthermore, supervisor toward notary must be taken in term of moral and ethical profession in order to guarantee of legal protection and certainty for the community.

Supervision of notary is preventive and curative activities that are carried out toward notary performance. Based on formulation mentioned above, it can be concluded that the supervision toward notary also includes guidance for the notary in performing their duty. Supervising toward notary aims to ensure the fulfilment of requirements in protecting public interests. Notary is appointed by the state not for self-interest of the notary but for the interests of community that are served. Notary is entrusted position in which it contains of huge responsibility according to law and morality. A notary will not be able to carry out his duties, as required by law and the interests of the general public, even though he/she has sufficient legal skills, but not based on responsibility and without any appreciation of the dignity and values toward his/her position as notary.

As official public who carry out some duties and authorities in making authentic deeds in which it is also can be regarded as state document, therefore it is necessary for the notary to obtain legal protection mainly related to these duties and obligations. Article 66 paragraph (1) UUJN Amendment aims to protect notary as the public official from arbitrary acts of law enforcers within process of criminal case examination in regard to the publication of authentic deeds. Law enforcers mentioned above are police officer, Public Prosecutor, and Judge in which they are not arbitrarily justified in taking copy of the Minuta deed since it is a confidential state document (Sulastini \& Aditya, 2010).

The Minister of Law and Human Rights as an executive state department appoints the Honorary Council of Notary to monitor, guide, and manage the performance of notary. Therefore, it can be said that the Honorary Council of notary is the representative of the Minister of Law and Human Rights which holds authority to monitor, guide and manage the performance of notary (Adjie, 2008).

The existence of the Honorary Council of notary is expected to be able to provide legal protection for Notaries mainly related to legal privilege (Verschoningsplicht) held by notary. Legal protection is a picture law enforcement namely justice, legal certainty and expediency (Utomo, Memahami Pelaksanaan Tugas Jabatan Pejabat Pembuat Akta Tanah, 2019). Furthermore, legal protection is a form of protection aimed at legal subjects in accordance with the rule of law all forms: written and unwritten, preventive, repressive (coercive) in accordance to legal enforcement of the law. Legal protection must considered several stages, namely legal protection is born from legal provisions coupled with legal regulations that have been given by the community in which they are agreed to regulate behavioural relations between community members, individuals, and the government which they consider to represent the interests of the community.

Legal privilege (Verschoningsplicht) provides instructions to the Notary Public on the importance of confidential position that must be maintained. It can be understood that the meaning contained in the provisions of UUJN Amendments concerning notary liability means notary has no obligation to speak and he/she is obliged not to speak or rather not to provide information about matters related to the performance of his / her duties, except to the certain parties that are permitted by the law. This privilege aims to protect public interests in which within public interests there are individual interests that require notarial services, mainly concerning publication of written evidence, in form of authentic deed, therefore it is appropriate to enforce legal privilege.

\section{CONCLUSION}

A Notary Position is a trusted position where the community entrusts their will to the notary. Therefore it contains to confidential position that must be maintained by the notary. The existence of the Honorary Council of Notary is intended to provide legal protection for Notary related to obligation of confidential position of notary in order to avoid arbitrary acts from law enforcers within the process of criminal proceedings relating to publication of authentic deeds. Legal protection provided by the Honorary Council of Notary to the notary for the permission to take the Minuta deed and the calling of a Notary are along with providing legal protection for the parties making deeds before a Notary. Legal protection in this case is not intended for the notary as a person but rather for protecting the position attached to it.

\section{REFERENCES}

Adjie, H. (2008). ukum Notaris Indonesia (Tafsir Tematik Terhadap UU No. 30 Tahun 2004 Tentang Jabatan Notaris). Bandung: Refika Aditama.

Kie, T. T. (2000). Studi Notariat, Serba-Serbi Praktek Notaris. Jakarta: Ichtiar Baru.

Kohar, A. (1984). Notaris Berkomunikasi. Bandung: Alumni.

Sing, K. T. (1978). Rahasia Pekerjaan Dokter dan Advokat. Jakarta: Gramedia.

Sulastini, E. T., \& Aditya, W. (2010). Pertanggungjawaban Notaris Terhadap Akta yang Berindikasi Pidana. Bandung: Refika Aditama.

Utomo, H. I. (2019). Memahami Pelaksanaan Tugas Jabatan Pejabat Pembuat Akta Tanah. Yogyakarta: 
Phoenix Publisher.

Utomo, H. I. (2017). Pelaksanaan Tugas Jabatan Notaris : Bahan Diskusi Dalam Menghadapi Ujian Kode Etik Notaris. Universitas Narotama Surabaya, 10. 